\title{
Damp-Heat Induced Performance Degradation for InGaP/GaAs/Ge Triple-Junction Solar Cell
}

\author{
Hwen-Fen Hong, ${ }^{1}$ Tsung-Shiew Huang, ${ }^{1}$ Wu-Yih Uen, ${ }^{2}$ and Yen-Yeh Chen ${ }^{3}$ \\ ${ }^{1}$ Department of Materials Science and Engineering, National Tsing Hua University, Hsinchu 30013, Taiwan \\ ${ }^{2}$ Department of Electronic Engineering, College of Electrical Engineering and Computer Science, \\ Chung Yuan Christian University, Chungli 32023, Taiwan \\ ${ }^{3}$ Institute of Nuclear Energy Research, 1000 Wenhua Road, Jiaan Village, Longtan, Taoyuan 32546, Taiwan
}

Correspondence should be addressed to Hwen-Fen Hong; d937537@oz.nthu.edu.tw

Received 23 December 2013; Revised 8 January 2014; Accepted 10 January 2014; Published 24 April 2014

Academic Editor: Ting-Jen Hsueh

Copyright (C) 2014 Hwen-Fen Hong et al. This is an open access article distributed under the Creative Commons Attribution License, which permits unrestricted use, distribution, and reproduction in any medium, provided the original work is properly cited.

\begin{abstract}
We performed accelerated tests on sealed and nonsealed InGaP/InGaAs/Ge triple-junction (TJ) solar cells in a complex high temperature and high humidity environment and investigated the electrical properties over time. The degradation of energy conversion efficiency in nonsealed cells was found to be more serious than that in sealed cells. The short-circuit current $\left(I_{\mathrm{SC}}\right)$, opencircuit voltage $\left(V_{\mathrm{OC}}\right)$, and fill factor $(\mathrm{FF})$ of sealed cells changed very slightly, though the conversion efficiency decreased $3.6 \%$ over $500 \mathrm{~h}$ of exposure. This decrease of conversion efficiency was suggested to be due to the deterioration of silicone encapsulant. The $I_{\mathrm{SC}}, V_{\mathrm{OC}}$, and FF of nonsealed cells decreased with increasing exposure time. By EL and SEM analysis, the root causes of degradation can be attributed to the damage and cracks near the edge of cells induced by the moisture ingress. It resulted in shunt paths that lead to a deterioration of the conversion efficiency of solar cell by increasing the leakage current, as well as decreasing open-circuit voltage and fill factor of nonsealed solar cells.
\end{abstract}

\section{Introduction}

TJ solar cells are fabricated using organometallic vapor phase epitaxy (OMVPE) to deposit subcells of GaInP and GaInAs on Ge substrate [1]. A TJ solar cell consists of three individual subcells that are stacked on top of each other to form a series connection. The individual subcells are connected to each other through very thin tunnel junction film of several nanometers. These tunnel junctions are typically very thin to allow the tunneling mechanism to dominate the majority carrier transport [2]. Among solar technologies, TJ solar cells have attracted increasing attention owing to their very high conversion efficiencies $[3,4]$ as well as long term stability [5-7]. TJ solar cells based on III-V semiconductors are being evaluated globally in concentrator photovoltaic (CPV) systems designed to supplement electricity generation for utility companies. III-V TJ solar cells, with demonstrated efficiency over $40 \%$ since 2007 [8], strongly reduce the cost of CPV systems and make III-V multijunction concentrator cells the technology of choice for most concentrator systems today. The world's highest energy conversion efficiency solar cells with 44.7\% have been demonstrated on June 2013 [9]. In fact, the III-V TJ solar cells have nanoscale thin films which can take good advantage of solar light from $300 \mathrm{~nm}$ to $1800 \mathrm{~nm}$.

In recent years, there have been many research groups that reported the improvements of III-V triple-junction concentration solar cells using different approaches [10-13]. In addition to pursuing high efficiency for III-V concentration solar cells, one should also understand the degradation mechanism of these devices to maintain their reliability. The reliability of III-V single-junction, dual-junction, and multijunction concentration solar cells has been analyzed by some research groups using different methods and strategies. However, so far, the studies about the reliability on GaInP/GaInAs/Ge concentration solar cells were rather rare and almost focused on clarifying the degradation induced by thermal stress [14-17]. It is believed that the understanding 
of mechanism of degradation caused by moisture will favor the upgrading qualities of III-V triple-junction concentration solar cells. Once the reliability of III-V triple-junction concentration solar receivers is realized, the prospect of the HCPV systems will be more clearly demonstrated.

The aim of this study is to examine the degradation mechanism of $\mathrm{GaInP} / \mathrm{GaInAs} / \mathrm{Ge}$ triple-junction solar receivers by accelerated damp-heat environment test. These results are considered to be helpful for researchers to understand the causes of degradation and improve the efficiency and stability of TJ solar cells.

\section{Samples Preparation and Test Description}

IEC62108 standard is the most commonly used test method for concentrator solar receivers. In this study, III-V InGaP/InGaAs/Ge concentrator solar cells were exposed to $85^{\circ} \mathrm{C}$ and $85 \%$ relative humidity without electrical bias according to IEC 62108 standard. A photograph of typical concentrator solar receiver used in this study is shown in Figure 1, including concentrator solar cell, protection silicone layer, bypass diode, ceramic substrate, and heat sink. The cells with active area of $0.3025(0.55 \times 0.55) \mathrm{cm}^{2}$ were glued to aluminum plates using an adhesive. The schematic structure of the GaInP/GaInAs/Ge triple-junction concentrator solar cell is shown in Figure 2, and the schematic graph of crosssection of silicone sealed cell is shown in Figure 3. Those concentration solar cells are divided into two groups. One is denoted as test $A$ with 20 pieces of cells protected with optical silicone layer. The other is denoted as test $B$ with 20 cells without any protection layer. Test $B$ is designed to provide a contrast to test $A$, which is favorable for analyzing the predominant factor in degradation of solar cells. The experimental time sequence of accelerated degradation test for tests $A$ and $B$ is the same.

Finally, we have performed both dark current versus voltage (DIV) and light current versus voltage (LIV) tests for all solar cells to analyze the variation of their electrical characteristics. We have also visually inspected samples before humidity exposure and after 100, 200, 300, 400, and $500 \mathrm{~h}$ of exposure. According to IEC62108 standard, samples should be tested over 2000 h; however, we have observed apparent degradation in nonsealed cells after $500 \mathrm{~h}$ of dampheat exposure. We therefore report these results in advance. A solar simulator (WACOM WXS-155S-L2) was used to measure the LIV. In the meanwhile, scanning electron micrographic (SEM) and electroluminescent (EL) examinations were applied to understand the root cause of degradation in this investigation.

\section{Results and Discussion}

The collected average performance data of sealed and bare solar cells are shown in Table 1 . It can be seen that the energy conversion efficiency of sealed cells degraded by 3 4\% after $500 \mathrm{~h}$ exposure. However, $V_{\mathrm{oc}}$ and FF except $I_{\mathrm{sc}}$ changed only very slightly in sealed cells. On the surface of the sealed cells, no significant morphological change was observable.

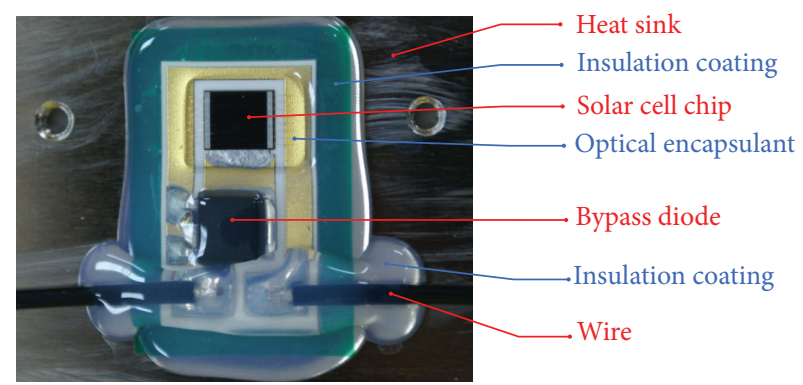

FIGURE 1: Picture of concentrator solar receiver used in this study.

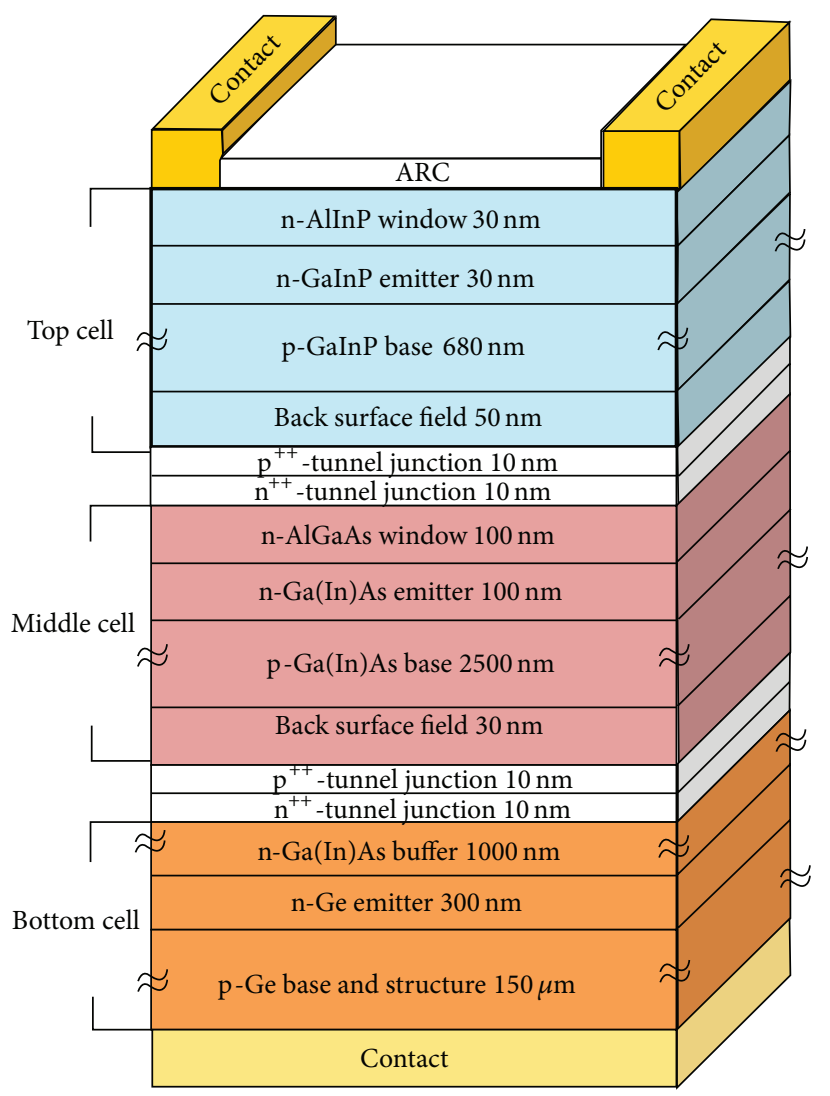

FIGURE 2: Schematic structure of GaInP/GaInAs/Ge triple-junction solar cell.

TABLE 1: Performance of sealed and bare solar cells after damp-heat test.

\begin{tabular}{lcccc}
\hline Type & $\Delta I_{\mathrm{SC}} / I_{\mathrm{SC}(\text { initial) }}$ & $\Delta V_{\mathrm{OC}} / V_{\mathrm{OC}(\text { initial) }}$ & $\Delta \mathrm{FF} / \mathrm{FF}_{\text {(initial) }}$ & $\Delta \eta / \eta_{\text {(initial) }}$ \\
\hline Sealed & $-0.978 \%$ & $-0.071 \%$ & $-0.013 \%$ & $-3.59 \%$ \\
Bare & $-1.098 \%$ & $-0.102 \%$ & $-1.531 \%$ & $-5.55 \%$ \\
\hline
\end{tabular}

Figure 4 shows the typical dark $I-V$ curves of solar cells which were measured sequentially after each $100 \mathrm{~h}$ time interval. In general, the dark current of III-V solar cells as a function of bias voltage can be formulated by double exponential terms [18] as described in

$$
I_{\text {dark }}(V)=I_{\text {diff }}(V)+I_{\text {scr }}(V) \text {. }
$$




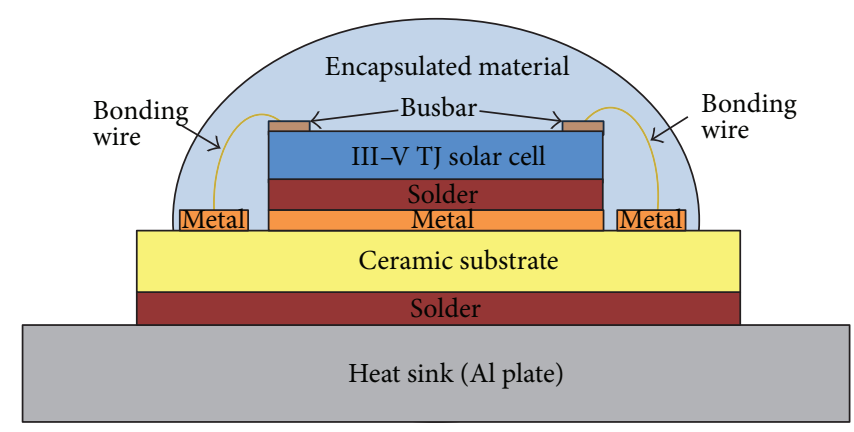

FIGURE 3: Schematic graph of cross-section of concentrator solar receiver.

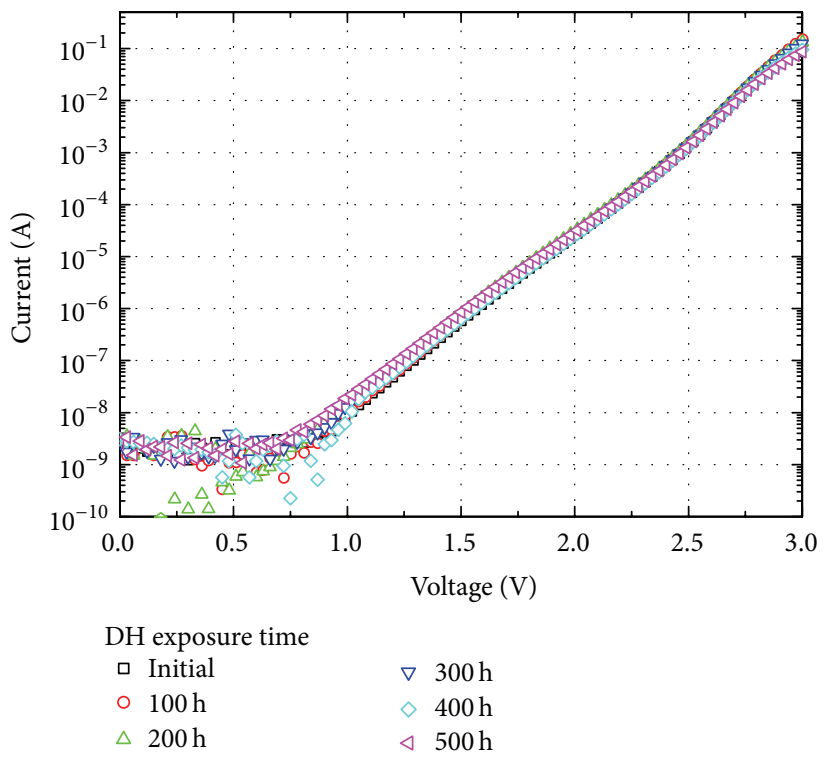

FIGURE 4: Typical dark $I$ - $V$ curves of sealed cells measured sequentially after each step of damp-heat exposures.

Here, $I_{\text {diff }}(V)$ denotes the diffusion current in the neutral region and $I_{\text {scr }}(V)$ is related to the generation-recombination current in the depletion region. In general, the dark current is dominated by recombination current at low voltage and by diffusion current at high voltage. Since the decrease of FF was very small, this implied that both shunt and series resistances did not change apparently. From Figure 4, it is noteworthy that almost all sealed cells showed similar dark $I-V$ characteristics. No obvious difference can be recognized between these $I-V$ curves implying that both $I_{\text {diff }}$ and $I_{\text {scr }}$ did not change even after $500 \mathrm{~h}$ of exposure. In other words, there were no significant defects generated, which would increase the recombination current [19]. We believe that there is no deterioration of electrical characteristics in sealed cells. Hence, the losses of conversion efficiency were suggested to be due to encapsulant material. These results are similar to that reported previously by McIntosh et al. [20]. They reported that water moisture can diffuse into silicone materials, then the water molecules will scatter incident light and decrease the transmission coefficient of silicone materials, thus decrease the short-circuit current and conversion efficiency.
As for bare solar cells, the average energy conversion efficiency of 20 cells after $500 \mathrm{~h}$ of exposure degraded by $5 \sim 6 \%$, which is higher than the data of sealed cells. It is worth mentioning that there are two cells that are denoted as $\mathrm{S} 1$ and $\mathrm{S} 2$ and degraded over $10 \%$ on energy conversion efficiency. The light $I-V$ and dark $I-V$ curves of $S 1$ are shown in Figures 5(a) and 5(b), respectively. The variation of $I_{\mathrm{SC}}$ was not apparent over the damp-heat test. The degradation of $V_{\mathrm{OC}}$ was also not apparent before $400 \mathrm{~h}$ exposure; however, $V_{\mathrm{OC}}$ decreased significantly after $500 \mathrm{~h}$ of exposure. From the EL images of $400 \mathrm{~h}$ and $500 \mathrm{~h}$ exposed samples, as shown in Figure 6, some different color zones near the edge of cells can be observed. It reveals that some defects were generated after $500 \mathrm{~h}$ of damp-heat test. Evidently, these defects increase $I_{\mathrm{scr}}(V)$, therefore, result in the elevation of $I_{\text {dark }}$ and a significant decrease in $V_{\mathrm{OC}}$.

Figures 7(a) and 7(b) show the light $I-V$ curves and dark $I-V$ curves of S2 cell before and after 100, 200, 300, 400 , and $500 \mathrm{~h}$ of exposure in damp-heat environment, respectively. It exhibits a linear (ohmic) behavior after $500 \mathrm{~h}$ of exposure. It is well known that a lot of commercially produced silicon solar cells have a problem caused by local 


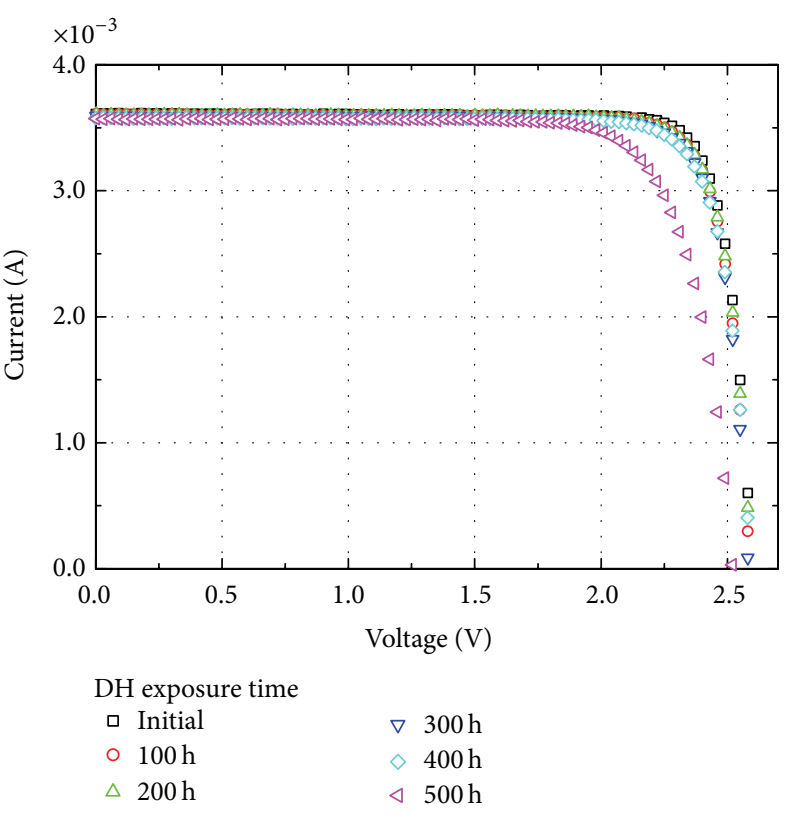

(a)

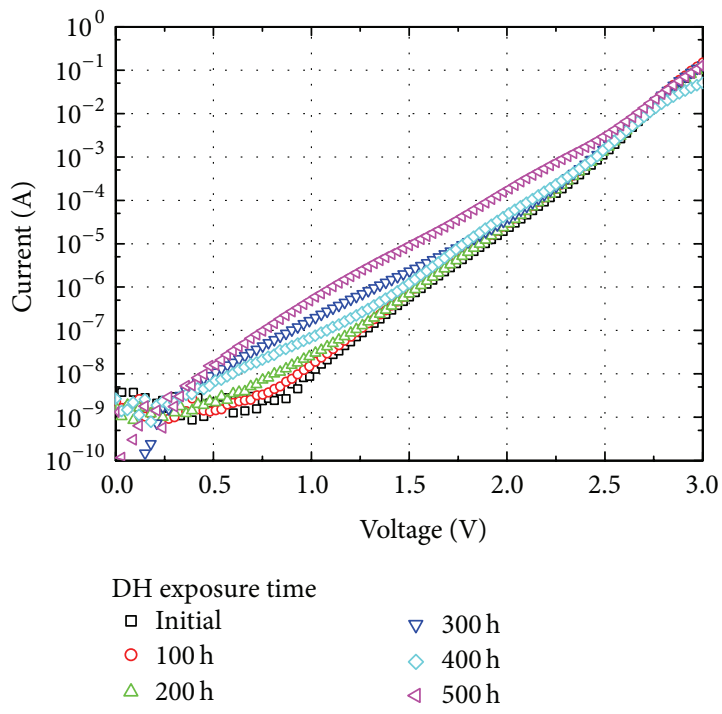

(b)

FIGURE 5: (a) Light $I-V$ and (b) dark $I-V$ curves of bare cell S1 measured sequentially after each step of damp-heat exposures.

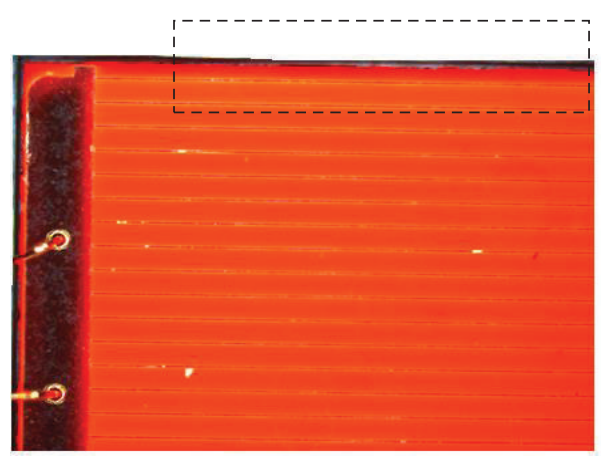

(a)

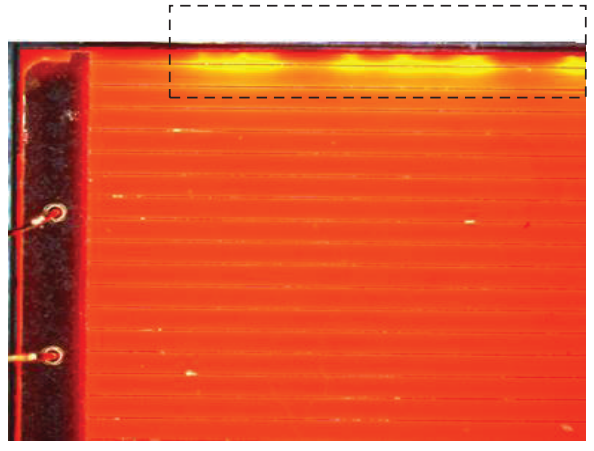

(b)

Figure 6: EL images of sample S1 after $400 \mathrm{~h}$ (a) and $500 \mathrm{~h}$ (b) of exposure.

short circuits called shunts [21]. These shunts may lead to a deterioration of the conversion efficiency of solar cells by increasing the leakage current and decreasing both the opencircuit voltage and the fill factor of the solar cells. Shunts in solar cells often localized at the cell edges. Some of these edge shunts have a linear $I-V$ (ohmic) behavior and some of them have a nonlinear $I-V$ (diode-like). To analyze the cause of the sudden degradation after $500 \mathrm{~h}$ of exposure, we performed SEM and EDX examination for S2. Figure 8 shows the EL images of $\mathrm{S} 2$ after $400 \mathrm{~h}$ and $500 \mathrm{~h}$ of exposures. No obvious damage was found in the EL image of $400 \mathrm{~h}$ exposed sample; however bright zones, as marked by dashedrectangle, appeared in the $500 \mathrm{~h}$ of exposed sample. We inspected the bright zone with SEM and found that a particle existed in the zone, which was furthermore identified by EDX to be a segregated particle composed mainly of Au. Therefore, the bright zone exhibited low resistance, and leakage current resulted in shunts. The SEM micrograph of Figure 9 also shows a crack at the edge, as marked by a circle. Figure 10 shows an enlarged SEM micrograph of crack region. We furthermore performed EDX analysis and found that region $a$ is the $\mathrm{Ge}$ substrate, regions $\mathrm{b}$ and $\mathrm{c}$ are $\mathrm{GeO}_{\mathrm{x}}$, and region $\mathrm{d}$ is the epitaxial layer. The crack initiated in the nanoscaled epilayer, possibly induced by in-diffused moisture and part of $\mathrm{Ge}$ was oxidized into $\mathrm{GeO}_{\mathrm{x}}$. Both the EL and SEM analysis suggested that the shunt and leakage paths occurred in the edge of cells and resulted in the degradation.

\section{Conclusions}

We performed accelerated tests on both sealed and bare TJ concentrator solar cells in a damp-heat environment and investigated the degradation of electrical characteristics over time. Our results indicated that silicone encapsulant really protects solar receiver and resists moisture ingress; therefore, the performance of sealed cells is much better than unsealed 


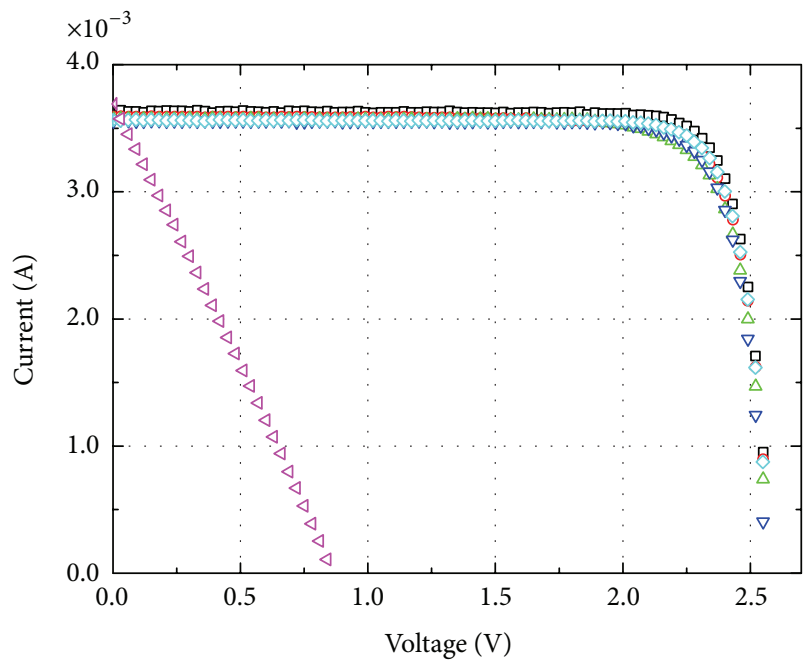

DH exposure time
口 Initial
- $100 \mathrm{~h}$
$\nabla 300 \mathrm{~h}$
$\diamond 400 \mathrm{~h}$
$\triangleleft 500 \mathrm{~h}$

(a)

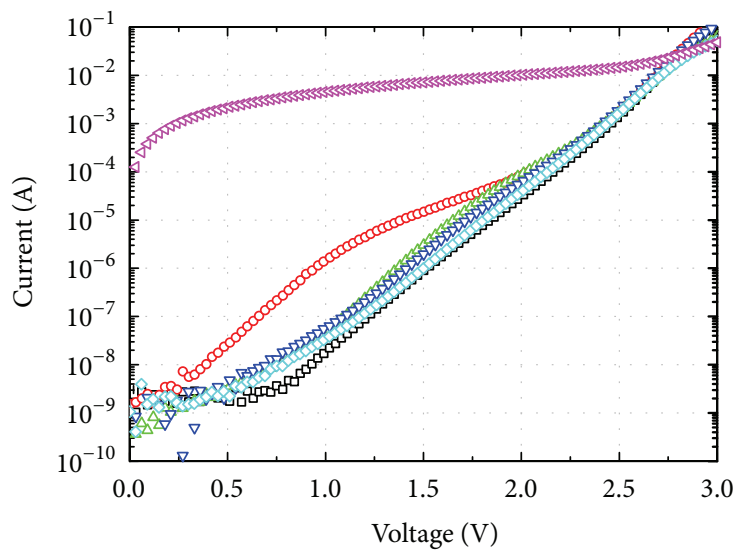

DH exposure time
$\square$ Initial
$\nabla 300 \mathrm{~h}$
- $100 \mathrm{~h}$
$\diamond 400 \mathrm{~h}$
$\triangle 200 \mathrm{~h}$
$\triangleleft 500 \mathrm{~h}$

(b)

Figure 7: (a) Light $I$-V and (b) dark $I-V$ curves of bare cell S2 measured sequentially after each step of damp-heat exposures.

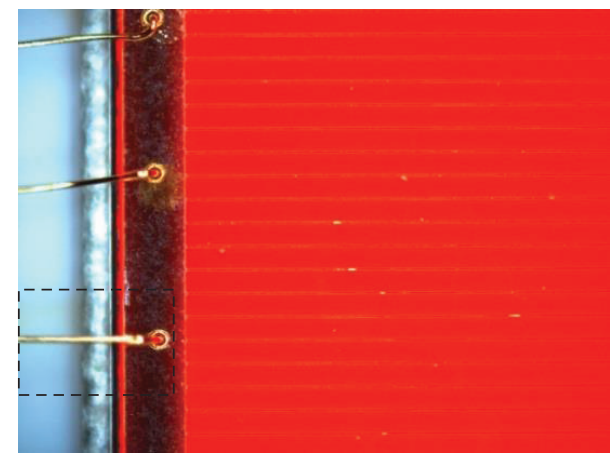

(a)

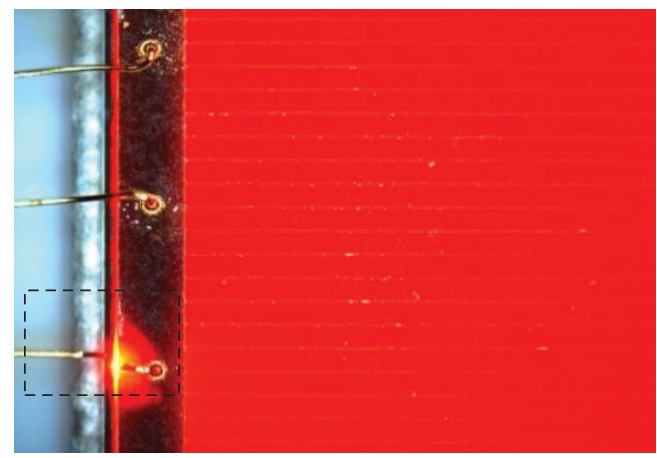

(b)

FIGURE 8: EL images of sample S2 after $400 \mathrm{~h}$ (a) and $500 \mathrm{~h}$ (b) of exposure.

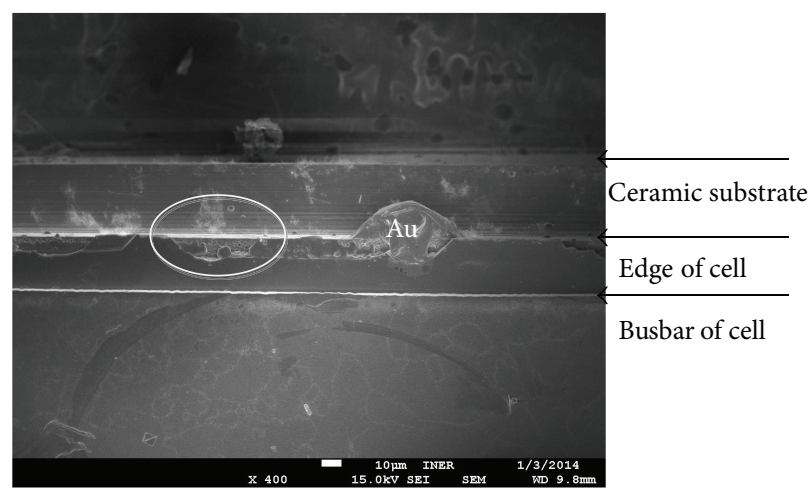

FIGURE 9: Cross-sectional SEM micrograph shows the crack and the Au particle in the edge of nonsealed solar cell. 


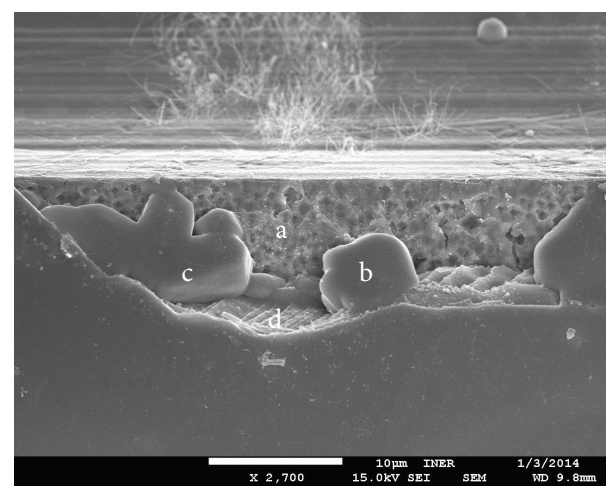

FIGURE 10: Cross-sectional SEM micrograph shows partial crack in the edge of nonsealed solar cell. Region a is the Ge substrate, regions $\mathrm{b}$ and $\mathrm{c}$ are $\mathrm{GeO}_{\mathrm{x}}$, and region $\mathrm{d}$ is the epitaxial layer as analyzed by EDX.

cells. However, careful selection of silicone material should be adopted to avoid the deterioration of silicone from moisture attack and to preserve the reliability. For bare cells, we found that $I_{\mathrm{sc}}, V_{\mathrm{oc}}$, and FF and conversion efficiency degraded after long time exposure to damp-heat environment. Both EL and SEM analysis indicated that the causes of degradation can be attributed to the damage and cracks in the edge of cells. The damage and cracks resulted in the leakage paths and increased recombination current. In the near future, we will investigate solar cells with different silicone materials and increase the damp-heat test time in order to clarify the degradation mechanism of silicone-sealed solar cells and to understand the lifetime under the influence of damp-heat environment.

\section{Conflict of Interests}

The authors declare that there is no conflict of interests regarding the publication of this paper.

\section{References}

[1] C. M. Fetzer, X. Q. Liu, J. Chang et al., "Progress in large area organometallic vapor phase epitaxy for III-V multijunction photovoltaics," Journal of Crystal Growth, vol. 352, no. 1, pp. 181185, 2011.

[2] G. J. Bauhuis, P. Mulder, and J. J. Schermer, "Ultra-thin, high performance tunnel junctions for III-V multijunction cells," in Proceedings of the 38th IEEE Photovoltaic Specialists Conference (PVSC '12), pp. 909-912, Austin, Tex, USA, June 2012.

[3] M. A. Green, K. Emery, Y. Hishikawa, W. Warta, and E. D. Dunlop, "Solar cell efficiency tables (version 42)," Progress in Photovoltaics, vol. 21, no. 5, pp. 827-837, 2013.

[4] J. L. Hou, S. J. Chang, T. J. Hsueh, C. H. Wu, W. Y. Weng, and J. M. Shieh, "InGaP/GaAs/Ge triple-junction solar cells with $\mathrm{ZnO}$ nanowires," Progress in Photovoltaics, vol. 21, no. 8, pp. 16451652, 2013.

[5] S. P. Philipps, G. Peharz, R. Hoheisel et al., "Energy harvesting efficiency of III-V triple-junction concentrator solar cells under realistic spectral conditions," Solar Energy Materials and Solar Cells, vol. 94, no. 5, pp. 869-877, 2010.
[6] M. Yamaguchi, T. Takamoto, A. Khan, M. Imaizumi, S. Matsuda, and N. J. Ekins-Daukes, "Super-high-efficiency multijunction solar cells," Progress in Photovoltaics, vol. 13, no. 2, pp. 125-132, 2005.

[7] C. G. Zimmermann, C. Noemayr, M. Kolb, and A. Rucki, "A mechanism of solar cell degradation in high intensity, high temperature space missions," Progress in Photovoltaics, vol. 21, no. 4, pp. 420-435, 2013.

[8] R. R. King, D. C. Law, C. M. Fetzer et al., " $40 \%$ efficient metamorphic GaInP/GaInAs/Ge multijunction solar cells," Applied Physics Letters, vol. 90, no. 18, Article ID 183516, 2007.

[9] 2013, http://sharp-world.com/corporate/news/130614.html.

[10] J. H. Ermer, R. K. Jones, P. Hebert et al., "Status of C3MJ+ and C4MJ production concentrator solar cells at spectrolab," IEEE Journal of Photovoltaics, vol. 2, no. 2, pp. 209-213, 2012.

[11] F. Dimroth, W. Guter, J. Schöne et al., "Metamorphic GaInP/GaInAs/Ge triple-junction solar cells with $\gg 41 \%$ efficiency," in Proceedings of the 34th IEEE Photovoltaic Specialists Conference (PVSC '09), pp. 001038-001042, Philadelphia, Pa, USA, June 2009.

[12] W. Guter, J. Schöne, S. P. Philipps et al., "Current-matched triple-junction solar cell reaching $41.1 \%$ conversion efficiency under concentrated sunlight," Applied Physics Letters, vol. 94, no. 22, Article ID 223504, 3 pages, 2009.

[13] G. S. Kinsey, P. Pien, P. Hebert, and R. A. Sherif, "Operating characteristics of multijunction solar cells," Solar Energy Materials and Solar Cells, vol. 93, no. 6-7, pp. 950-951, 2009.

[14] I. Rey-Stolle and C. Algora, "High-irradiance degradation tests on concentrator GaAs solar cells," Progress in Photovoltaics, vol. 11, no. 4, pp. 249-254, 2003.

[15] P. Espinet, C. Algora, J. R. González, N. Núnez, and M. Vázquez, "Degradation mechanism analysis in temperature stress tests on III-V ultra-high concentrator solar cells using a 3D distributed model," Microelectronics Reliability, vol. 50, no. 9-11, pp. 18751879, 2010.

[16] J. R. González, M. Vázquez, N. Núñez, C. Algora, I. Rey-Stolle, and B. Galiana, "Reliability analysis of temperature step-stress tests on III-V high concentrator solar cells," Microelectronics Reliability, vol. 49, no. 7, pp. 673-680, 2009.

[17] N. Núñez, M. Vázquez, J. R. González, C. Algora, and P. Espinet, "Novel accelerated testing method for III-V concentrator solar cells," Microelectronics Reliability, vol. 50, no. 9-11, pp. 18801883, 2010.

[18] J. Nelson, The Physics of Solar Cells, Imperial College Press, London, UK, 2002.

[19] O. Ueda, "Reliability issues in III-V compound semiconductor devices: optical devices and GaAs-based HBTs," Microelectronics Reliability, vol. 39, no. 12, pp. 1839-1855, 1999.

[20] K. R. McIntosh, N. E. Powell, A. W. Norris, J. N. Cotsell, and B. M. Ketola, "The effect of damp-heat and UV aging tests on the optical properties of silicone and EVA encapsulants," Progress in Photovoltaics, vol. 19, no. 3, pp. 294-300, 2011.

[21] M. Langenkamp and O. Breitenstein, "Classification of shunting mechanisms in crystalline silicon solar cells," Solar Energy Materials and Solar Cells, vol. 72, no. 1-4, pp. 433-440, 2002. 

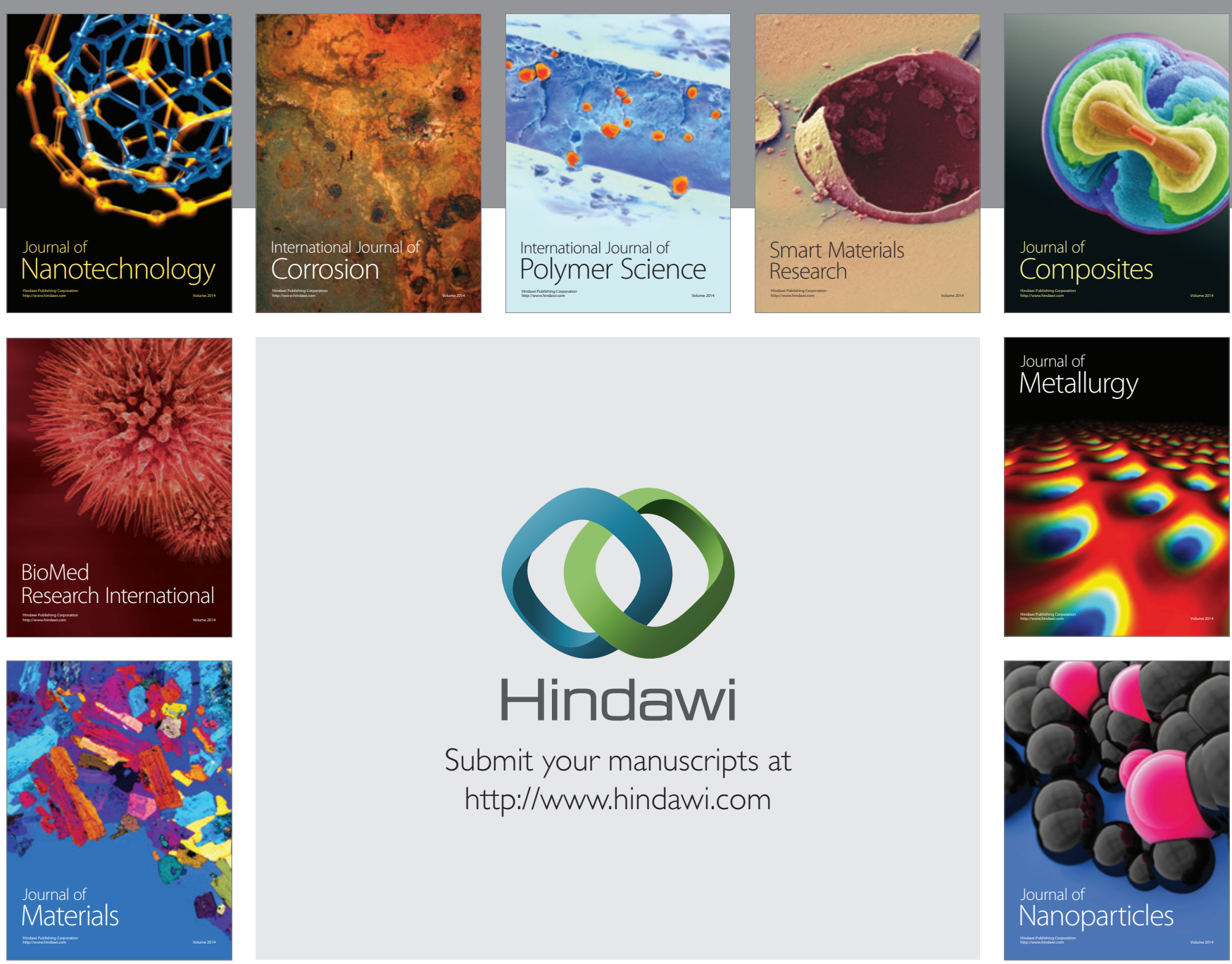

Submit your manuscripts at http://www.hindawi.com
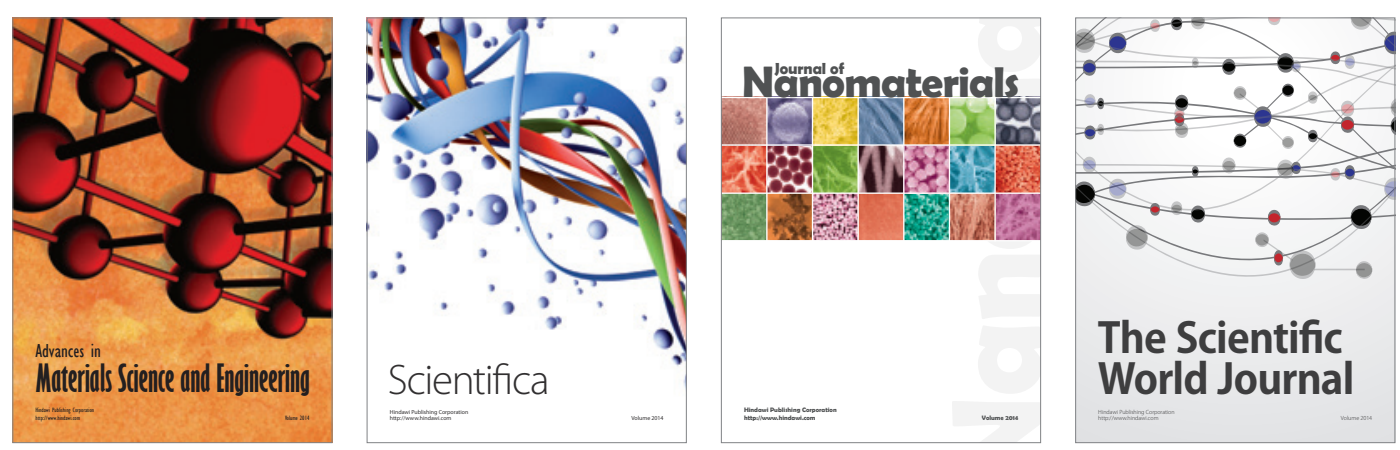

\section{The Scientific World Journal}
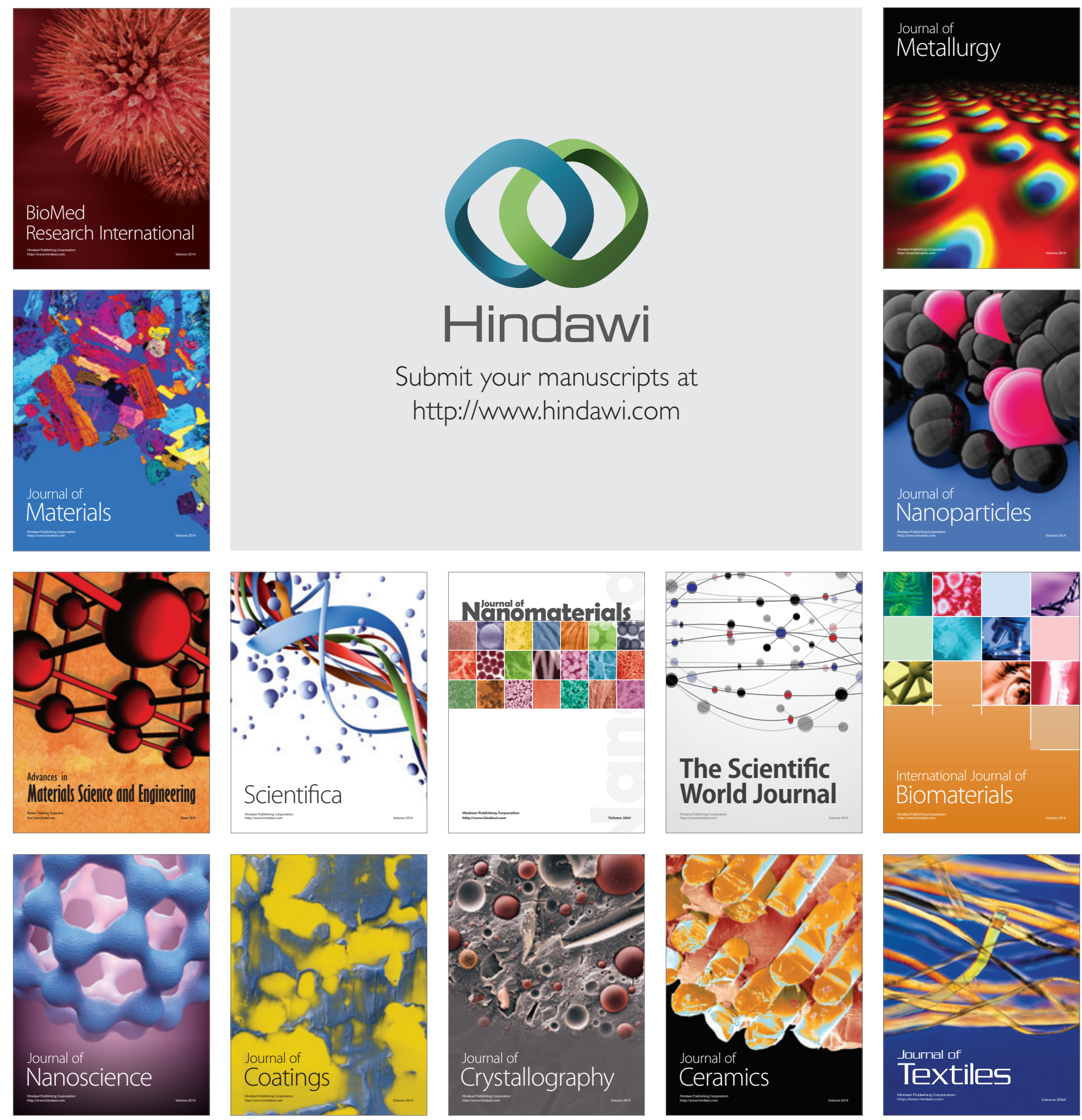